\title{
Methylation profiles of MIR34 gene family in Vietnamese patients suffering from breast and lung cancers
}

\author{
VO THI THUONG LAN ${ }^{1}$, HO VAN SON ${ }^{2}$, VU LAN TRANG ${ }^{3}$, NGUYEN THU TRANG $^{1}$, \\ NGUYEN THI PHUONG ${ }^{1}$, NGUYEN LINH TOAN ${ }^{4}$ and PHAM ANH THUY DUONG ${ }^{5}$
}

\begin{abstract}
${ }^{1}$ Faculty of Biology, VNU University of Science, Hanoi; ${ }^{2}$ Department of Pathophysiology, 175 Hospital, Ho Chi Minh, Vietnam; ${ }^{3}$ Laboratoire des Biomolécules, Sorbonne Universités, Université Pierre et Marie Curie University Paris 06, École Normale Supérieure, Paris Sciences et Lettres Research University, Centre National de la Recherche Scientifique, Institut National de la Santé Et de la Recherche Médicale, Assistance Publique Hôpitaux de Paris, 75012 Paris, France;

${ }^{4}$ Department of Pathophysiology, Medical University, Ha Dong; ${ }^{5}$ Department of Gene Technology, Vinmec Research Institute of Stem Cell and Gene Technology, Hanoi, Vietnam
\end{abstract}

Received December 2, 2017; Accepted April 3, 2018

DOI: $10.3892 / \mathrm{mmr} .2018 .9182$

\begin{abstract}
The three genes encoding small non-coding microRNA $(M I R) 34 a, M I R 34 b$ and $M I R 34 c$ act as tumor-suppressor genes. Their aberrant expressions regulated by DNA methylation have been frequently found in various types of cancer. In the present study, the DNA promoter methylation profiles of the MIR34 gene family were analyzed using the methylation specific polymerase chain reaction in order to clarify their association with breast and lung cancer, non-cancerous or normal adjacent tissues. The methylation frequency of $M I R 34 a$ was significantly higher in breast cancer (49.37\%) compared with normal adjacent tissues (30.38\%). The methylation frequency of $M I R 34 b / c$ was 59.49 and $62.03 \%$ in breast cancer and normal adjacent tissues, respectively. MIR34a methylation showed a significant concordance with that of MIR34b/c only in breast cancer tissue. MIR34a methylation was significantly associated with cancer and the invasive ductal carcinoma type of breast cancer $(\mathrm{P}=0.015$ and $\mathrm{P}=0.02$, respectively). Methylation frequency of MIR34a and MIR34b/c was 48.42 and $56.84 \%$ in lung cancer, and 47.22 and $51.39 \%$ in pulmonary diseases, respectively. No significant association was observed between the methylation status of MIR34a and $M I R 34 b / c$, and the clinicopathological features of lung cancer or with those of non-cancerous pulmonary diseases. Promoter methylation of MIR34a and MIR34b/c occurs frequently and concomitantly in breast and lung cancer, as well as in pulmonary diseases tissues, but not in breast normal tissues
\end{abstract}

Correspondence to: Professor Vo Thi Thuong Lan, Faculty of Biology, VNU University of Science, 334 Nguyen Trai, Hanoi, Vietnam

E-mail: vothithuonglan@hus.edu.vn

Key words: MIR34a, MIR34/b/c genes, breast cancer, lung cancer, pulmonary diseases, methylation specific polymerase chain reaction adjacent to tumor. These results of the present study emphasize the involvement of MIR34 methylation in human diseases, including cancer. Furthermore, MIR34a methylation may be a promising marker for a subtype of breast cancer.

\section{Introduction}

DNA methylation at cytosines in $\mathrm{CpG}$ islands located in promoters is well known as one of the earliest molecular alteration occurring during carcinogenesis and specific for the malignant state (1). Over the past few years, there have been increasing evidences asserting the role of DNA methylation at promoter of genes encoding small non coding microRNAs (MIRs) that act as posttranscriptional regulators of gene expression $(2,3)$. Aberrant expression of microRNAs regulated by DNA methylation is involved in many cellular processes such as DNA repair, cell cycle, apoptosis, through which they promote cell differentiation, proliferation, malignant transformation and tumorigenesis $(4,5)$. For example, the down-regulation of MIR129-2 by DNA methylation regulates breast cancer cell proliferation and apoptosis (6). Moreover, MIR449c expression, which was significantly down-regulated by DNA methylation in osteosarcoma cancer, was negatively correlated with tumor size and tumor stages (7). In addition, integrating DNA methylation data with microRNA expression profile in various types of cancers including lung, colon and breast has been extensively explored by genome wide analysis recently $(8,9)$.

Among the huge number of microRNA genes, the MIR34 gene family, which consists of three genes MIR34a, MIR34b and MIR34c, has been the focus of numerous studies in cancer research. All the three MIR34 genes are transcriptionally regulated by p53 protein, a regulator of cell cycle and apoptosis; therefore, they act as tumor suppressor genes by targeting many oncogenes related to proliferation, apoptosis and invasion $(10,11)$. Numerous studies have demonstrated the direct link between dysregulations concerning MIR34 family and epigenetic and genetic mechanisms in cancers. 
For instance, MIR34a targets the proto-oncogene c-SRC to attenuate tumor growth in triple-negative breast cancer (12), or programmed death ligand 1 (PDL1) to modulate the tumor immune response in non small cell lung cancer (13). Stahlhut and Slack revealed that combinatorial action of MIR34a and microRNA let-7 effectively synergizes with erlotinib to suppress non-small cell lung cancer cell proliferation (14). MIR34b and MIR34c, which share a common primary transcript, function as metastasis suppressors in lung adenocarcinoma $(15,16)$. A recent study on circulating $M I R 34 s$ in 173 patients with triple-negative breast cancer indicated that MIR34a, MIR34b and MIR34c expression was respectively correlated with tumor grade $(\mathrm{P}=0.038)$, lymph node positivity $(\mathrm{P}=0.027)$ and distant metastasis $(\mathrm{P}<0.001)$ (17). Importantly, the aberrant low expression of MIR34s was associated with promoter methylation. Indeed, data integration from 104 studies on microRNAs revealed that MIR34s are silenced by DNA methylation in the highest number of cancer types (18). Epigenetic inactivation of the MIR34a was found in ovarian, colorectal, lung, kidney and breast cancer cell lines $(19,20)$. The presence of MIR34b/c promoter methylation was significantly associated with the absence of its transcripts and with metastasis formation in primary tumors of colon, lung, head and neck, melanomas and breast cancers (21). Siemens et al (22) showed that MIR34a methylation is involved in the up-regulation of c-Met, Snail, and $\beta$-catenin proteins, which was associated with the metastasis distance of colon cancer cells to the liver. Patients after surgery of lung cancer with aberrant methylation of $M I R 34 b / c$ had a high probability of recurrence and poor prognosis $(\mathrm{P}=0.026)$ (23). Furthermore, molecular events from negative surgical margin have been extremely investigated because of their predictive and prognostic values for tumor progression, local recurrence, metastasis and overall survival (24). Multi-platform analyses of DNA defects, epigenetics, and gene expression in cancer-adjacent tissues have extensively been performed recently to provide integrative data to the clinic $(25,26)$. DNA methylation that has occurred at the primary tumor is believed to progressively spread outwards to surrounding tissues $(27,28)$. Increased DNA methylation level in ductal carcinoma in situ is related with future development of invasive breast cancer and with the cancer metastasis distance (29,30). Currently, MIR34 methylation profile in normal adjacent and tumor tissues, and its correlation with clinicopathological features have been frequently reported to gastrointestinal cancer. For instance, MIR34 methylation occurs in colorectal normal adjacent (43.9\%) and tumor tissues (79.3\%) and correlated with positive lymph node $(\mathrm{P}=0.01)(31)$. Similarly, $M I R 34 b / c$ methylation was considerably different between adjacent $(22.7 \%)$ and tumors $(70 \%)$ in gastric cancer (32). However, differences in MIR34 methylation profile in either non-cancerous or normal adjacent tissues as compared with breast and lung cancer tissues have been rarely described so far while both types of these cancers are the first and second common types of cancer and leading cause of cancer death all over the world (33). Therefore, investigating the methylation profile of the MIR34 genes in both types of cancer vs. normal adjacent tissues and non-cancerous tissues and moreover their association with the clinicopathological features would provide a comprehensive evaluation on the synergy of these potential methylation biomarkers for cancer diagnosis.

In this study, we investigated the methylation status at the promoter of the genes encoding $M I R 34 a / b / c$ in breast cancer vs. normal adjacent tissues, as well as in non-cancerous lung diseases vs. lung cancer, with samples coming from Vietnamese patients. The objective is to evaluate the methylation profiles of these genes both individually and in an integrative manner in order to establish new integrative methylation biomarkers for cancer detection. Furthermore, the comparison of the methylation profiles of these genes in cancer vs. non-cancerous or normal adjacent tissues has highlighted the epigenetically concomitant changes of these genes in tissues that are physiologically different such as breast and lung.

\section{Materials and methods}

Sample collection. Surgically resected specimens from breast carcinomas and matched adjacent tissues were collected from 79 breast cancer patients having undergone mastectomy at the Department of Pathology, National Cancer Hospital K (Hanoi, Vietnam) between 2012 and 2013. The corresponding adjacent tissue samples were selected $3-5 \mathrm{~cm}$ away from the site at which the primary tumor was obtained. Breast tumor and corresponding adjacent tissues were snap-frozen in liquid nitrogen immediately after resection and examination by pathologists, and stored at $-80^{\circ} \mathrm{C}$ until further used. Formalin-fixed, paraffin-embedded (FFPE) tissue specimens were collected from 95 lung cancer patients and 72 patients suffering from non-cancerous lung diseases (whose classification was examined by pathologists) at the Department of Pathology, 175 Hospital (Ho Chi Minh, Vietnam) during 2016. Informed consent was obtained from patients in written form and the study was approved by the guidelines of the VNU University of Science ethical committee in Vietnam (106-YS.06-2015.07).

Genomic DNAs extraction and bisulfite modification. Genomic DNAs were extracted from freshly frozen breast or FFPE lung tissues by using the QIAampDNA Mini kit or QIAamp DNA FFPE Tissue kit (Qiagen, Inc., Valencia, CA, USA), and treated with sodium bisulfite by using the EpiTect Bisulfite kit (Qiagen, Inc.). During the treatment, the unmethylated cytosines of the genomic DNAs were converted into uracils, but the methylated cytosines remained unchanged (34). Polymerase chain reaction (PCR) realized on native DNA using primer sets specific to methylated sequences was performed to confirm the accuracy of the primer sets. PCR realized on the bisulfite-treated DNA using primer sets specific to unmethylated sequences of the $\beta$-globin gene was performed to determine the efficiency of bisulfite conversion (35).

Methylation specific PCR (MSP). The methylation status of the investigated genes was evaluated by using MSP to amplify bisulfite treated DNA with primers that distinguish methylated (M) and unmethylated (U) DNA (36). MIR34a gene locates on chromosome 1 and is transcribed from the minus strand. The MIR34a gene structure is described by Tarasov et al (37) and the $\mathrm{CpG}$ island in its promoter is indicated by Lodygin et al (19). $M I R 34 b / c$ gene locates on chromosome 16 and is transcribed 
Table I. MSP primers for analysis of MIR34a, MIR34b/c methylation.

\begin{tabular}{|c|c|c|c|}
\hline Primers & Sequence (5'-3') & $\begin{array}{l}\text { Amplicon } \\
\text { size (bp) }\end{array}$ & MSP conditions \\
\hline \multicolumn{4}{|c|}{ MIR34a EF570049.1 } \\
\hline miR-34a-meF & TTTTGGGTAGGCGCGTTTCGC & Round 1: 147 & $\begin{array}{l}94^{\circ} \mathrm{C} 5 \mathrm{~min}, 40 \mathrm{cycles} \text { of }\left(94^{\circ} \mathrm{C} 30 \mathrm{sec}, 60^{\circ} \mathrm{C}\right. \\
\left.10 \mathrm{sec}, 72^{\circ} \mathrm{C} 15 \mathrm{sec}\right), 72^{\circ} \mathrm{C} 5 \mathrm{~min}\end{array}$ \\
\hline miR-34a-meR & CCAATCCCGCCGAACACGAAA & & \\
\hline miR-34a-meF & TTTTGGGTAGGCGCGTTTCGC & Round 2: 100 & $\begin{array}{l}94^{\circ} \mathrm{C} 5 \mathrm{~min}, 40 \mathrm{cycles} \text { of }\left(94^{\circ} \mathrm{C} 30 \mathrm{sec}, 63^{\circ} \mathrm{C}\right. \\
\left.10 \mathrm{sec}, 72^{\circ} \mathrm{C} 15 \mathrm{sec}\right), 72^{\circ} \mathrm{C} 5 \mathrm{~min}\end{array}$ \\
\hline miR-34a-meR1 & GCCCCCGCCTAAACTAACG & & \\
\hline miR -34a-unF & $\begin{array}{l}\text { GGTGGTGTTTTGTGATTTAGT } \\
\text { GGTGGT }\end{array}$ & 143 & $\begin{array}{l}94^{\circ} \mathrm{C} 5 \mathrm{~min}, 40 \mathrm{cycles} \text { of }\left(94^{\circ} \mathrm{C} 30 \mathrm{sec}, 63^{\circ} \mathrm{C}\right. \\
\left.10 \mathrm{sec}, 72^{\circ} \mathrm{C} 15 \mathrm{sec}\right), 72^{\circ} \mathrm{C} 5 \mathrm{~min}\end{array}$ \\
\hline miR-34-unR & $\begin{array}{l}\text { CAAAACCAATCCCACCAAACA } \\
\text { CAAAATC }\end{array}$ & & \\
\hline \multicolumn{4}{|c|}{ MIR34b/c BC021736 } \\
\hline $\mathrm{miR}-34 \mathrm{~b} / \mathrm{c}-\mathrm{meF}$ & TCGTTTCGTTTCGCGTTCGTT & 93 & $\begin{array}{l}94^{\circ} \mathrm{C} 1 \mathrm{~min}, 40 \mathrm{cycles} \text { of }\left(94^{\circ} \mathrm{C} 30 \mathrm{sec}, 66^{\circ} \mathrm{C}\right. \\
\left.30 \mathrm{sec}, 72^{\circ} \mathrm{C} 30 \mathrm{sec}\right), 72^{\circ} \mathrm{C} 5 \mathrm{~min}\end{array}$ \\
\hline $\mathrm{miR}-34 \mathrm{~b} / \mathrm{c}-\mathrm{meR}$ & GCCGCTCTAAACGACCGAAT & & \\
\hline miR-34b/c-unF & $\begin{array}{l}\text { TTGTGGGGTTTTAAGGATGGTT } \\
\text { GGTTGTTT }\end{array}$ & 160 & $\begin{array}{l}94^{\circ} \mathrm{C} 1 \mathrm{~min}, 40 \text { cycles of }\left(94^{\circ} \mathrm{C} 30 \mathrm{sec}, 66^{\circ} \mathrm{C}\right. \\
\left.30 \mathrm{sec}, 72^{\circ} \mathrm{C} 30 \mathrm{sec}\right), 72^{\circ} \mathrm{C} 5 \mathrm{~min}\end{array}$ \\
\hline $\mathrm{miR}-34 \mathrm{~b} / \mathrm{c}-\mathrm{unR}$ & СССТТСАССТССТСААСССАААС & & \\
\hline
\end{tabular}

miR, microRNA; MSP, methylation specific polymerase chain reaction; F, forward; R, reverse; un, unmethylated sequences; me, methylated sequences.

from the plus strand. The $\mathrm{CpG}$ island of $M I R 34 \mathrm{~b} / \mathrm{c}$ promoter locates in the upstream sequence of the BTG4 gene as described by Toyota et al (38). Based on these reports, we look for the sequences corresponding to MIR34a, MIR34b/c promoters and designed the MSP primer sets used in our study. The primers for detecting the methylation status of MIR34s were designed based on the primer designing tool for MSP method (http://www. urogene.org/methprimer/index1.html). The primer sequences, MSP conditions and amplicon lengths are shown in Table I. Bisulfite treated DNAs were subjected to single or nested PCR depending on the particular targeted genes. The MSP products were resolved by electrophoresis in $8 \%$ polyacrylamide gel, then stained with ethidium bromide and imaged with the UVP, LLC (Upland, CA, USA). DNA extracted from lymphocytes of healthy volunteers and treated with bisulfite was used as a positive control for unmethylation of the targeted genes in numerous reports in which the MSP method was also applied $(23,36)$. Water with no DNA template was included in each PCR reaction as a control for contamination. All MSP reactions were performed in duplicate. The methylation status was confirmed by direct sequencing of the MSP products for a subset of samples from each assay.

Statistical analysis. Chi-square test was used to determine the difference in MIR34s methylation levels between cancer and non-cancerous/normal adjacent tissues. The Kappa statistic was used to assess the agreement between two dichotomous variables such as the concordance between the methylation status of genes analyzed two by two in a given tissue type or the concordance between the methylation status of individual gene in tumor and adjacent normal tissues. Chi-square test and Fisher's exact test was used to examine the association of the methylation status of individual or combined genes with clinicoathological characteristics. For all statistical analyses, a $\mathrm{P}<0.05$ was considered to indicate a statistically significant difference. All analyses were done by using the STATA program version 12 (StataCorp LP, College Station, TX, USA; https://www.stata.com/).

\section{Results}

In order to assess the methylation status of MIR34 genes, we first set up an MSP assay and verified its specificity, since we have previously shown that false positive results from the MSP assay could be due to the MSP primers amplifying nonspecifically untreated genomic DNAs (35). Native DNAs were subjected to MSP analysis with the primer sets specific to the methylated status of the targeted sequences MIR34a and $M I R 34 b / c$. No MSP products were amplified from untreated DNAs extracted from lymphocytes of healthy donors (Fig. 1), confirming that the MSP primers were specific for the methylated targets and that false positive results have been avoided.

Genomic DNAs were subsequently treated with bisulfite and then subjected to the MSP assays. Representative results of the MSP reactions were illustrated in Fig. 1. The MSP products specific to methylated sequences of the MIR34 promoters were directly sequenced. The results showed that all cytosines in the $\mathrm{CpG}$ sites remained cytosines and the cytosines alone were converted to thymidines (data not shown), indicating the completely conversion of genomic DNA by bisulfite treatment. 


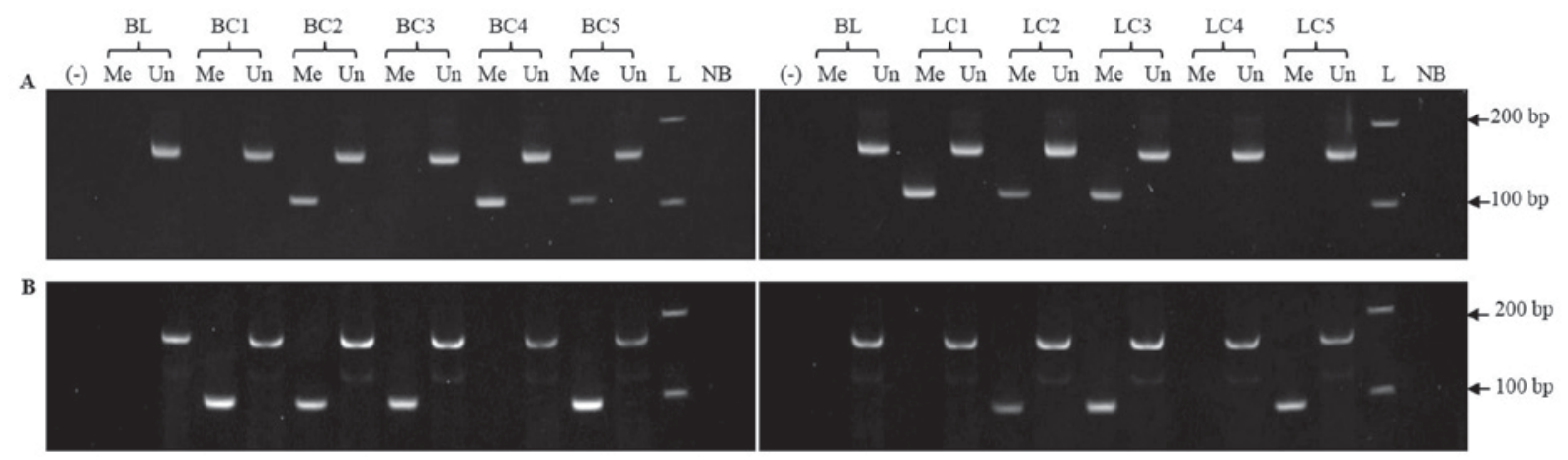

Figure 1. Representative analysis of methylation specific polymerase chain reaction products showing the detection of unmethylated sequences (Un) and methylated ones (Me) of the (A) MIR34a, (B) MIR34b/c genes from breast tumor (BC) and lung tumor (LC) tissues. BL, Treated bisulfite DNA isolated from blood lymphocytes of healthy volunteers; NB, Untreated bisulfite DNA isolated from blood lymphocytes of healthy volunteers; (-), Negative control without DNA templates; L, DNA ladders. MSP product sizes of the methylated sequences of MIR34a and MIR34b/c are 100 and 93 bp, respectively.

The MSP analysis revealed that methylation of MIR34 promoters occurred in all analyzed tissues (breast cancer and adjacent tissues as well as in lung cancer and non-cancerous tissues). Among 79 pairs of matched breast cancer and adjacent tissues, MIR34a methylation occurred with the frequency of $49.37 \%$ in cancer tissue, which is significantly higher than its frequency of $30.38 \%$ in normal adjacent tissue $(\mathrm{P}=0.015)$. These frequencies for MIR $34 \mathrm{~b} / \mathrm{c}$ methylation were 59.49 and $62.03 \%$, respectively, with no significant difference. The methylation frequencies of MIR34a and MIR34b/c in lung cancer (48.42 and 56.84\%) were similar to those in non-cancerous lung diseases (47.22 and $51.39 \%$ ) (Table II).

As assessed by the calculation of the Kappa coefficient, the methylation status of MIR34a showed a significant concordance with that of $M I R 34 \mathrm{~b} / \mathrm{c}$ in breast cancer tissue but not in normal adjacent tissues $(\mathrm{OR}=2.12,95 \% \mathrm{CI}$ : 1.04-4.28, $\mathrm{P}=0.04)$. On the contrary, a significant concordance of the methylation status of both MIR34a and MIR34b/c genes was observed in lung cancer as well as in non-cancerous pulmonary diseases $(\mathrm{P}=0.0001 ;<0.0001)$ (Table II). Additionally, the methylation status of each gene promoter was also analyzed in association with clinicopathological features such as the histological tumor type, the tumor grade and the metastasis status (Table III). For breast cancer, the results showed that the methylation frequency of MIR34a was significantly associated with tumor type IDC $(\mathrm{P}=0.02)$. The univariate logistic analysis indicated that MIR34a was more methylated in the IDC type than in the other carcinoma types $(\mathrm{OR}=6.17,95 \% \mathrm{CI}: 1.25-30.32, \mathrm{P}=0.03)$. However, no significant differences in the methylation frequency of the $M I R 34 \mathrm{~b} / \mathrm{c}$ gene were associated with clinical features of breast cancer patients such as the tumor grade and the metastasis status, nor with the patient' age. As far as lung cancer and non-cancerous pulmonary diseases are concerned, there was no significant association of the methylation frequency of MIR34a and MIR34b/c with any clinical features nor with the patient' age or sex.

\section{Discussion}

Over the past few years, there have been increasing evidences asserting the role of small non coding microRNA genes in different cellular processes promoting cell differentiation, proliferation, malignant transformation and tumorigenesis $(4,5)$. Among the huge number of microRNA genes, the MIR34 genes have been extensively focused on because they play a key role as tumor suppressors in cancer $(10,11)$. Currently, clinical trial on cancer therapy based on MIR34a has already shown antitumor activity in refractory advanced solid tumor (39). Therefore, investigating the aberrant expression of the MIR34 family in cancer has been being an attractive subject. The down regulation of all the three members of the MIR34 family via promoter methylation, the correlation between MIR34 methylation with cancer type, grade, metastasis and survival, as well as the aberrant expression of MIR34 targeted genes have been extensively reported in multiple types of cancers including breast and lung cancers $(12,17,19,40)$. However, an integrative comparison of MIR34 methylation between both type of cancers vs. normal tissues adjacent to breast cancer or non-cancerous pulmonary disease tissues has rarely been described so far, while both types of these cancers are the first and second common types of cancer (33). From a more general standpoint over the literature, the difference in MIR34s methylation frequency among non-cancerous, cancer and normal adjacent tissues has been only explored in several types of cancer such as prostate, colon, gastric and skin cancer $(19,31,32)$. In this study, we revealed that MIR34 methylation was frequently found not only in breast cancer but also in normal tissue adjacent to tumor, with the lowest frequency being around $30 \%$ (Table II). Interestingly, MIR34a methylation occurred with significantly higher frequency in breast cancer than in adjacent tissues (Table II), and showed a concordance with MIR34b/c methylation only in breast cancer tissues (Table III). Concerning lung cancer, we showed here that methylation of MIR34a and MIR34b/c occurs in non-cancerous lung disease tissues with similar frequency than in lung cancer (Table II), suggesting their role in cancerous and non-cancerous lung disease onset and progression. Indeed, it is worth noting that no MIR34a methylation and a tiny frequency of MIR34b/c methylation have been detected in normal tissue adjacent to tumor of lung cancer $(16,40,41)$. In addition, the contribution of MIR methylation to the pathogenesis of pulmonary fibrosis has been described previously (42). In our study, the concomitant methylation of MIR34a and MIR34b/c in breast 
Table II. Methylation profile of the MIR34 genes in breast and lung cancers.

\begin{tabular}{|c|c|c|c|c|}
\hline \multirow[b]{2}{*}{ Tissue } & \multicolumn{4}{|c|}{ Number of methylated cases (\%) } \\
\hline & $m i R a$ & P-value & $m i R b / c$ & P-value \\
\hline Breast cancer & & $0.015^{\mathrm{a}}$ & & 0.745 \\
\hline Tumor $(\mathrm{n}=79)$ & $\begin{array}{c}39(49.37) \\
{[38.34 ; 60.39]}\end{array}$ & & $\begin{array}{c}47(59.49) \\
{[48.67 ; 70.32]}\end{array}$ & \\
\hline Normal adjacent tissue $(\mathrm{n}=79)$ & $\begin{array}{c}24(30.38) \\
{[20.24 ; 40.52]}\end{array}$ & & $\begin{array}{c}49(62.03) \\
{[51.32 ; 72.73]}\end{array}$ & \\
\hline Lung cancer & & 0.878 & & 0.483 \\
\hline Tumor $(n=95)$ & $\begin{array}{c}46(48.42) \\
{[38.37 ; 58.47]}\end{array}$ & & $\begin{array}{c}54(56.84) \\
{[46.88 ; 66.80]}\end{array}$ & \\
\hline Pulmonary diseases $(n=72)$ & $\begin{array}{c}34(47.22) \\
{[35.69 ; 58.75]}\end{array}$ & & $\begin{array}{c}37(51.39) \\
{[39.84 ; 62.93]}\end{array}$ & \\
\hline
\end{tabular}

${ }^{\text {aSignificant }}(\mathrm{P}<0.05)$. The methylation status was indicated as (+) for methylated and (-) for unmethylated. $m i R a$, MIR34a; $m i R b / c$, MIR34b/c. Numbers in parentheses, when not preceded by ' $n=$ ', indicate the methylation frequency. Numbers in brackets indicate the $95 \%$ confidence interval of the methylation frequency. miR, microRNA.

Table III. Association of the methylation status of the MIR34s genes with the clinicopathologicalcharacteristics of the 79 breast cancer, 95 lung cancer and 72 non-cancerous pulmonary disease patients.

A, Breast cancer

\begin{tabular}{|c|c|c|c|c|c|c|c|}
\hline \multirow[b]{2}{*}{ Feature } & \multirow[b]{2}{*}{ No. of patients } & \multicolumn{2}{|c|}{ miR34a } & \multirow[b]{2}{*}{ P-value } & \multicolumn{2}{|c|}{$\mathrm{miR} 34 \mathrm{~b} / \mathrm{c}$} & \multirow[b]{2}{*}{ P-value } \\
\hline & & Un & $\mathrm{Me}$ & & Un & $\mathrm{Me}$ & \\
\hline Histological tumor type & 79 & & & $0.015^{\mathrm{b}}$ & & & 0.274 \\
\hline IDC & 67 & 30 & 37 & & 25 & 42 & \\
\hline ILC & 5 & 3 & 2 & & 2 & 3 & \\
\hline Other & 7 & 7 & 0 & & 5 & 2 & \\
\hline Tumor grade & 65 & & & 0.999 & & & 0.382 \\
\hline Grade 1 & 3 & 1 & 2 & & 0 & 3 & \\
\hline Grade 2 & 54 & 24 & 30 & & 22 & 32 & \\
\hline Grade 3 & 8 & 4 & 4 & & 2 & 6 & \\
\hline Metastasis & 79 & & & $0.934^{\mathrm{a}}$ & & & $0.753^{\mathrm{a}}$ \\
\hline No & 51 & 26 & 25 & & 20 & 31 & \\
\hline Yes & 28 & 14 & 14 & & 12 & 16 & \\
\hline Age, years & 79 & & & $0.749^{\mathrm{a}}$ & & & $0.192^{\mathrm{a}}$ \\
\hline$<50$ & 29 & 14 & 15 & & 9 & 20 & \\
\hline$\geq 50$ & 50 & 26 & 24 & & 23 & 27 & \\
\hline
\end{tabular}

B, Lung cancer

\begin{tabular}{|c|c|c|c|c|c|c|c|}
\hline \multirow[b]{2}{*}{ Feature } & \multirow[b]{2}{*}{ No. of patients } & \multicolumn{2}{|c|}{ miR34a } & \multirow[b]{2}{*}{ P-value } & \multicolumn{2}{|c|}{$\mathrm{miR} 34 \mathrm{~b} / \mathrm{c}$} & \multirow[b]{2}{*}{ P-value } \\
\hline & & Un & $\mathrm{Me}$ & & Un & $\mathrm{Me}$ & \\
\hline Histological tumor type & 95 & & & 0.809 & & & 0.786 \\
\hline NSCLC & 72 & 38 & 34 & & 30 & 42 & \\
\hline SCLC & 1 & 0 & 1 & & 0 & 1 & \\
\hline Other & 22 & 11 & 11 & & 11 & 11 & \\
\hline
\end{tabular}


Table III. Continued.

B, Lung cancer

\begin{tabular}{|c|c|c|c|c|c|c|c|}
\hline \multirow[b]{2}{*}{ Feature } & \multirow[b]{2}{*}{ No. of patients } & \multicolumn{2}{|c|}{$\operatorname{miR} 34 a$} & \multirow[b]{2}{*}{ P-value } & \multicolumn{2}{|c|}{$\mathrm{miR} 34 \mathrm{~b} / \mathrm{c}$} & \multirow[b]{2}{*}{ P-value } \\
\hline & & Un & $\mathrm{Me}$ & & Un & $\mathrm{Me}$ & \\
\hline Stage & 79 & & & 0.739 & & & 0.311 \\
\hline I & 2 & 1 & 1 & & 0 & 2 & \\
\hline II & 28 & 17 & 11 & & 11 & 17 & \\
\hline III & 49 & 25 & 24 & & 25 & 24 & \\
\hline Sex & 94 & & & $0.877^{\mathrm{a}}$ & & & $0.961^{\mathrm{a}}$ \\
\hline Female & 21 & 21 & 20 & & 18 & 23 & \\
\hline Male & 28 & 28 & 25 & & 23 & 30 & \\
\hline Age, years & 86 & & & 0.999 & & & 0.999 \\
\hline$<50$ & 10 & 5 & 5 & & 4 & 6 & \\
\hline$\geq 50$ & 76 & 41 & 35 & & 35 & 41 & \\
\hline EGFR mutation & 44 & & & 0.480 & & & 0.484 \\
\hline No & 11 & 3 & 8 & & 4 & 7 & \\
\hline Yes & 33 & 15 & 18 & & 16 & 17 & \\
\hline
\end{tabular}

C, Lung diseases

\begin{tabular}{|c|c|c|c|c|c|c|c|}
\hline \multirow[b]{2}{*}{ Feature } & \multirow[b]{2}{*}{ No. of patients } & \multicolumn{2}{|c|}{ miR34a } & \multirow[b]{2}{*}{ P-value } & \multicolumn{2}{|c|}{$\mathrm{miR} 34 \mathrm{~b} / \mathrm{c}$} & \multirow[b]{2}{*}{ P-value } \\
\hline & & Un & $\mathrm{Me}$ & & Un & $\mathrm{Me}$ & \\
\hline Diagnosis & 71 & & & 0.768 & & & 0.306 \\
\hline Aspergillus & 9 & 3 & 6 & & 4 & 5 & \\
\hline Tuberculosis & 16 & 8 & 8 & & 8 & 8 & \\
\hline Pneumonia & 22 & 11 & 11 & & 8 & 14 & \\
\hline Pulmonary gas pressures & 17 & 10 & 7 & & 9 & 8 & \\
\hline Benign tumors & 3 & 2 & 1 & & 2 & 1 & \\
\hline Other diseases & 4 & 3 & 1 & & 4 & 0 & \\
\hline Sex & 72 & & & $0.554^{\mathrm{a}}$ & & & $0.118^{\mathrm{a}}$ \\
\hline Female & 25 & 12 & 13 & & 9 & 16 & \\
\hline Male & 47 & 26 & 21 & & 26 & 21 & \\
\hline Age, years & 70 & & & 0.863 & & & 0.863 \\
\hline$<50$ & 46 & 24 & 22 & & 22 & 24 & \\
\hline$\geq 50$ & 24 & 12 & 12 & & 12 & 12 & \\
\hline
\end{tabular}

P-values were calculated by the Fisher's test, ${ }^{\text {P }}$-values were calculated by the Chi-square test; ${ }^{b} \mathrm{P}<0.05$. IDC, invasive ductal carcinoma; ILC, invasive lobular carcinoma; NSCLC, non-small cell lung cancer; SCLC, small cell lung cancer; Me, methylated status; Un, unmethylated status; miR, microRNA.

cancer, lung cancer and non-cancerous lung disease tissues but not in normal tissue adjacent to breast cancer (Table II) emphasizes the role of MIR34 methylation in human diseases including cancers. Recently, Piletič and Kunej have reviewed that epigenetic regulation of 63 MIR genes including MIR34s was strongly correlated with 21 human diseases including 11 types of cancers (43).

Interestingly, MIR34a methylation was significantly correlated with tumor type IDC that consists of about $85 \%$ of all breast cancer types (Table III). Aberrant methylation of MIR34a has been found to have significant relation with the tumor grade from triple negative breast cancers or type II ovarian cancer $(17,44)$. However, we did not find any association between MIR34a methylation and breast tumor grade or lymph metastasis (Table III), even if this latter has been frequently reported in various cancer types such as colon, gastric and esophageal carcinomas $(22,31,45)$. Similarly, there were no association of MIR34a methylation with clinicopathological features of lung cancer as shown in our study (Table III), as also shown in a previous work from Wang and 
Table IV. Methylation status of the MIR34 genes assessed by the calculation of the $\kappa$ coefficient.

\begin{tabular}{|c|c|c|c|c|c|c|c|c|}
\hline \multirow[b]{2}{*}{$\begin{array}{l}\text { Methylation } \\
\text { status }\end{array}$} & \multicolumn{4}{|c|}{ Breast cancer methylation frequency $(\%)$} & \multicolumn{4}{|c|}{ Lung tissue methylation frequency $(\%)$} \\
\hline & $\begin{array}{l}\text { Tumor } \\
(\mathrm{n}=79)\end{array}$ & $\kappa(\mathrm{P}$-value $)$ & $\begin{array}{c}\text { Adjacent } \\
(\mathrm{n}=79)\end{array}$ & $\kappa(\mathrm{P}$-value $)$ & $\begin{array}{l}\text { Tumor } \\
(\mathrm{n}=95)\end{array}$ & $\kappa(\mathrm{P}$-value $)$ & $\begin{array}{c}\text { Pulmonary } \\
\text { diseases } \\
(\mathrm{n}=72)\end{array}$ & $\kappa(\mathrm{P}$-value $)$ \\
\hline$m i R a+/ m i R b / c+$ & $29(36.71)$ & & $17(21.52)$ & & $35(36.84)$ & & $26(36.11)$ & \\
\hline$m i R a+/ m i R b / c-$ & $10(12.66)$ & 0.29 & $7(8.86)$ & 0.098 & $11(11.58)$ & 0.37 & $8(11.11)$ & 0.47 \\
\hline$m i R a-/ m i R b / c+$ & $18(22.78)$ & $\left(0.0039^{\mathrm{a}}\right)$ & $32(40.51)$ & $(0.1432)$ & $19(20.00)$ & $\left(0.0001^{\mathrm{a}}\right)$ & $11(15.28)$ & $\left(<0.0001^{\mathrm{a}}\right)$ \\
\hline$m i R a-/ m i R b / c-$ & $22(27.85)$ & & $23(29.11)$ & & $30(31.58)$ & & $27(37.50)$ & \\
\hline
\end{tabular}

The methylation status in breast and lung cancers was indicated as (+) for methylated and (-) for unmethylated. $m i R a, M I R 34 a$; $m i R b / c$,

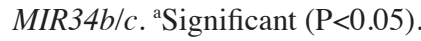

colleagues (23). These observations suggested that the aberrant $M I R 34 a$ methylation is preferentially associated with the development of different types of cancer. This could be supported by some other findings such as the strong association of MIR34a methylation with $p 53$ mutation in Li-Fraumeni syndrome, a highly penetrant cancer predisposition syndrome while on the contrary, no association with p53 mutation was found in ovarian cancer $(44,46)$.

On the contrary to MIR34a, MIR34b/c methylation did not differ from breast cancer to adjacent tissues as well as from lung cancer to non-cancerous tissues although it occurred in all investigated tissues in this study. Furthermore, no significant difference in $M I R 34 \mathrm{~b} / \mathrm{c}$ methylation was found associated with clinicopathological features of neither breast nor lung cancer. There were number of previous reports showing that $M I R 34 b / c$ methylation has a strong association with histologic type, pathologic stage and distance metastasis of breast and lung cancer $(17,21,40,47)$. However, it is worth noting that these conclusions have not always been consistent, since other studies did not detect any correlation of $M I R 34 \mathrm{~b} / \mathrm{c}$ methylation with tumor metastasis nor with clinicopathological features in lung, gastric and colon cancers $(16,31,32)$. The inconsistence of our result with previous studies may be explained by the difference concerning the tumor stage of analyzed samples. In our study, breast samples at grade 3 represented $12 \%$ [while it was $32 \%$ in the study by Zeng et al (17)], and lung cancer samples at stage IV represented 52\% [while no sample of this stage was analyzed in the study by Kim et al (40)]. In addition, there are limitations inherent to our study design that should be noted. The statistical analysis was limited to small samples. Moreover, the clinicopathological characteristics concerning hormone phenotypes ER/PR/HER2 presented some missing data. In our future studies, increasing number of fully characterized samples will be analysed to determine the correlation between MIR34 promoter methylation and subtypes of cancers.

To summarize, this study has chosen the non quantitative MSP method for the preliminary analysis of MIR34 methylation, a method that has been widely used in numerous studies (48) given its simplicity, high sensitivity and low cost. We have shown that the methylation frequently and concomitantly occurred at the promoters of MIR34 gene family in breast, lung cancer and pulmonary diseases. The encouraging results now prompt us to quantitatively investigate the correlation between MIR34 promoter methylation and the silencing of their expression, as well as with the expression level of the mRNAs targeted by MIR34s. In long term, this would allow optimizing detection techniques that are suitable for moderately equipped laboratories in developing countries, using MIR methylation markers in clinical applications for diagnosis of human disease including cancers.

\section{Acknowledgements}

The authors would like to thank Doan H. Van, Nguyen T. Duc and Thieu M. Thu at the Biomedical Lab, Faculty of Biology, VNU University of Science, Hanoi, Vietnam.

\section{Funding}

This study was financially supported by the Ministry of Science and Technology, Vietnam (grant no. 106-YS.06-2015.07).

\section{Availability of data and materials}

The datasets used and/or analyzed during the current study are available on reasonable request addressed to the corresponding author.

\section{Authors' contributions}

VTTL conceived, planned the experiments and wrote the manuscript. VLT contributed to the statistical analysis and manuscript writing. PATD carried out the statistical analysis. HVS and NLT contributed to sample preparation. NTT and NTP carried out the experiments.

\section{Ethics approval and consent to participate}

Informed consent for using tissue materials for scientific purposes and publication was obtained from patients in written form and the study was approved by the guidelines of the VNU University of Science ethical committee in Vietnam (no. 9/2016/108/HDTN, VNU University of Science, Hanoi, Vietnam). 


\section{Consent for publication}

Not applicable.

\section{Competing interests}

The authors declare that they have no competing interests.

\section{References}

1. Heyn $\mathrm{H}$ and Esteller M: DNA methylation profiling in the clinic: Applications and challenges. Nat Rev Genet 13: 679-692, 2012.

2. Hao X, Luo H, Krawczyk M, Wei W, Wang W, Wang J, Flagg K, Hou J, Zhang H, Yi S, et al: DNA methylation markers for diagnosis and prognosis of common cancers. Proc Natl Acad Sci USA 114: 7414-7419, 2017.

3. Strmsek Z and Kunej T: MicroRNA silencing by DNA methylation in human cancer: A literature analysis. Non-Coding RNA 1: 44-52, 2015.

4. Suzuki H, Maruyama R, Yamamoto E and Kai M: DNA methylation and microRNA dysregulation in cancer. Mol Oncol 6 : 567-578, 2012.

5. Kurozumi S, Yamaguchi Y, Kurosumi M, Ohira M, Matsumoto $\mathrm{H}$ and Horiguchi J: Recent trends in microRNA research into breast cancer with particular focus on the associations between microRNAs and intrinsic subtypes. J Hum Genet 62: 15-24, 2017.

6. Tang X,Tang J,Liu X,Zeng L, Cheng C,Luo Y,LiL, Qin SL,Sang Y, Deng LM and Lv XB: Downregulation of miR-129-2 by promoter hypermethylation regulates breast cancer cell proliferation and apoptosis. Oncol Rep 35: 2963-2969, 2016.

7. Li Q, Li H, Zhao X, Wang B, Zhang L, Zhang C and Zhang F: DNA methylation mediated downregulation of miR-449c controls osteosarcoma cell cycle progression by directly targeting oncogene c-Myc. Int J Biol Sci 13: 1038-1050, 2017

8. He DX, Gu F, Gao F, Hao JJ, Gong D, Gu XT, Mao AQ, Jin J, Fu L and Ma X: Genome-wide profiles of methylation, microRNAs, and gene expression in chemoresistant breast cancer. Sci Rep 6 : 24706,2016

9. Su Y, Fang $\mathrm{H}$ and Jiang F: Integrating DNA methylation and microRNA biomarkers in sputum for lung cancer detection. Clin Epigenetics 8: 109, 2016.

10. Zhu J, Zheng Z, Wang J, Sun J, Wang P, Cheng X, Fu L, Zhang L, Wang Z and Li Z: Different miRNA expression profiles between human breast cancer tumors and serum. Front Genet 5: 149, 2014

11. Agostini M and Knight RA: miR-34: From bench to bedside. Oncotarget 5: 872-881, 2014.

12. Adams BD, Wali VB, Cheng CJ, Inukai S, Booth CJ, Agarwal S, Rimm DL, Győrffy B, Santarpia L, Pusztai L, et al: miR-34a silences c-SRC to attenuate tumor growth in triple-negative breast cancer. Cancer Res 76: 927-939, 2016

13. Cortez MA,Ivan C, Valdecanas D, Wang X,PeltierHJ, Ye Y,Araujo L, Carbone DP, Shilo K, Giri DK, et al: PDL1 regulation by $\mathrm{p} 53$ via miR-34. J Natl Cancer Inst 108: pii: djv303, 2015.

14. Stahlhut $C$ and Slack FJ: Combinatorial action of microRNAs let-7 and miR-34 effectively synergizes with erlotinib to suppress non-small cell lung cancer cell proliferation. Cell Cycle 14: 2171-2180, 2015.

15. Corney DC, Flesken-Nikitin A, Godwin AK, Wang W and Nikitin AY: MicroRNA-34b and microRNA-34c are targets of p53 and cooperate in control of cell proliferation and adhesion-independent growth. Cancer Res 67: 8433-8438, 2007.

16. Daugaard I, Knudsen A, Kjeldsen TE, Hager H and Hansen LL: The association between miR-34 dysregulation and distant metastases formation in lung adenocarcinoma. Exp Mol Pathol 102: 484-491, 2017.

17. Zeng Z, Chen X, Zhu D, Luo Z and Yang M: Low expression of circulating MicroRNA-34c is associated with poor prognosis in triple-negative breast cancer. Yonsei Med J 58: 697-702, 2017.

18. Strmsek Z and Kunej T: Data integration of 104 studies related with microRNA epigenetics revealed that miR-34 gene family is silenced by DNA methylation in the highest number of cancer types. Discov J 2: e18, 2014.
19. Lodygin D, Tarasov V, Epanchintsev A, Berking C, Knyazeva T, Körner H, Knyazev P, Diebold J and Hermeking H: Inactivation of miR-34a by aberrant $\mathrm{CpG}$ methylation in multiple types of cancer. Cell Cycle 7: 2591-2600, 2008.

20. Vogt M, Munding J, Grüner M, Liffers ST, Verdoodt B, Hauk J, Steinstraesser L, Tannapfel A and Hermeking H: Frequent concomitant inactivation of miR-34a and $\mathrm{miR}-34 \mathrm{~b} / \mathrm{c}$ by $\mathrm{CpG}$ methylation in colorectal, pancreatic, mammary, ovarian, urothelial, and renal cell carcinomas and soft tissue sarcomas. Virchows Arch 458: 313-322, 2011

21. Lujambio A, Calin GA, Villanueva A, Ropero S, Sánchez-Céspedes M, Blanco D, Montuengaf LM, Rossic S, Nicolosoc MS, Fallerg WJ, et al: A microRNA DNA methylation signature for human cancer metastasis. Proc Natl Acad Sci USA 105: 13556-13561, 2008

22. Siemens H, Neumann J, Jackstadt R, Mansmann U, Horst D, Kirchner T and Hermeking H: Detection of miR-34a promoter methylation in combination with elevated expression of c-Met and $\beta$-catenin predicts distant metastasis of colon cancer. Clin Cancer Res 19: 710-720, 2013.

23. Wang Z, Chen Z, Gao Z, Li N, Li B, Tan F, Tan X, Lu N, Sun Y, Sun J, et al: DNA hypermethylation of microRNA-34b/c has prognostic value for stage I non-small cell lung cancer. Cancer Biol Ther 11: 490-496, 2011.

24. Casadio V, Molinari C, Calistri D, Tebaldi M, Gunelli R, Serra L, Falcini F, Zingaretti C, Silvestrini R, Amadori D and Zoli W: DNA methylation profiles as predictors of recurrence in non muscle invasive bladder cancer: An MS-MLPA approach. J Exp Clin Cancer Res 32: 94, 2013.

25. Troester MA, Hoadley KA, D'Arcy M, Cherniack AD, Stewart C, Koboldt DC, Robertson AG, Mahurkar S, Shen H, Wilkerson MD, et al: DNA defects, epigenetics, and gene expression in cancer-adjacent breast: A study from The Cancer Genome Atlas. NPJ Breast Cancer 2: 16007, 2016.

26. Cao B, Feng L, Lu D, Liu Y, Liu Y, Guo S, Han N, Liu X, Mao Y, He J, et al: Prognostic value of molecular events from negative surgical margin of non-small-cell lung cancer. Oncotarget 8: 53642-53653, 2016.

27. Yan PS, Venkataramu C, Ibrahim A, Liu JC, Shen RZ, Diaz NM, Centeno B, Weber F, Leu YW, Shapiro CL, et al: Mapping geographic zones of cancer risk with epigenetic biomarkers in normal breast tissue. Clin Cancer Res 12: 6626-6636, 2006.

28. Teschendorff AE, Gao Y, Jones A, Ruebner M, Beckmann MW, Wachter DL, Fasching PA and Widschwendter M: DNA methylation outliers in normal breast tissue identify field defects that are enriched in cancer. Nat Commun 7: 10478, 2016.

29. Johnson KC, Koestler DC, Fleischer T, Chen P, Jenson EG, Marotti JD, Onega T, Kristensen VN and Christensen BC: DNA methylation in ductal carcinoma in situ related with future development of invasive breast cancer. Clin Epigenetics 7: 75, 2015.

30. Schrijver WA, Jiwa LS, van Diest PJ and Moelans CB: Promoter hypermethylation profiling of distant breast cancer metastases. Breast Cancer Res Treat 151: 41-55, 2015

31. Wu XD, Song YC, Cao PL, Zhang H, Guo Q, Yan R, Diao DM, Cheng Y and Dang CX: Detection of miR-34a and miR-34b/c in stool sample as potential screening biomarkers for noninvasive diagnosis of colorectal cancer. Med Oncol 31: 894, 2014.

32. Suzuki H, Yamamoto E, Nojima M, Kai M, Yamano HO, Yoshikawa K, Kimura T, Kudo T, Harada E, Sugai T, et al: Methylation-associated silencing of microRNA-34b/c in gastric cancer and its involvement in an epigenetic field defect. Carcinogenesis 31: 2066-2073, 2010.

33. Siegel RL, Miller KD and Jemal A: Cancer statistics, 2016. CA Cancer J Clin 66: 7-30, 2016.

34. Clark SJ, Harrison J, Paul CL and Frommer M: High sensitivity mapping of methylated cytosines. Nucleic Acids Res 22: 2990-2997, 1994.

35. Lan VT, Ha NT, Uyen NQ, Duong NT, Huong NT, Thuan TB, Duong PA and To TV: Standardization of the methylation-specific PCR method for analyzing BRCA1 and ER methylation. Mol Med Rep 9: 1844-1850, 2014.

36. Herman JG, Graff JR, Myöhänen S, Nelkin BD and Baylin SB: Methylation-specific PCR: A novel PCR assay for methylation status of CpG islands. Proc Natl Acad Sci USA 93: 9821-9826, 1996.

37. Tarasov V, Jung P, Verdoodt B, Lodygin D, Epanchintsev A, Menssen A, Meister G and Hermeking H: Differential regulation of microRNAs by p53 revealed by massively parallel sequencing: miR-34a is a p53 target that induces apoptosis and G1-arrest. Cell Cycle 6: 1586-1593, 2007. 
38. Toyota M,Suzuki H, Sasaki Y,Maruyama R, Imai K, Shinomura Y and Tokino T: Epigenetic silencing of microRNA-34b/c and B-Cell translocation gene 4 is associated with $\mathrm{CpG}$ Island methylation in colorectal cancer. Cancer Res 68: 4123-4132, 2008.

39. Beg MS, Brenner AJ, Sachdev J, Borad M, Kang YK, Stoudemire J, Smith S, Bader AG, Kim S and Hong DS: Phase I study of MRX34, a liposomal miR-34a mimic, administered twice weekly in patients with advanced solid tumors. Invest New Drugs 35: 180-188, 2017.

40. Kim YH, Lee WK, Lee EB, Son JW, Kim DS and Park JY: Combined effect of metastasis-related microRNA, miR-34 and miR-124 family, methylation on prognosis of Non-Small-Cell lung cancer. Clin Lung Cancer 18: e13-e20, 2017.

41. Tan W, Gu J, Huang M, Wu X and Hildebrandt MA: Epigenetic analysis of microRNA genes in tumors from surgically resected lung cancer patients and association with survival. Mol Carcinog 54 (Suppl 1): E45-E51, 2015.

42. Dakhlallah D, Batte K, Wang Y, Cantemir-Stone CZ, Yan P, Nuovo G, Mikhail A, Hitchcock CL, Wright VP, Nana-Sinkam SP, et al: Epigenetic regulation of miR-17 92 contributes to the pathogenesis of pulmonary fibrosis. Am J Respir Crit Care Med 187: 397-405, 2013.

43. Piletič K and Kunej T: MicroRNA epigenetic signatures in human disease. Arch Toxicol 90: 2405-2419, 2016.
44. Schmid G, Notaro S, Reimer D, Abdel-Azim S, Duggan-Peer M, Holly J, Fiegl H, Rössler J, Wiedemair A, Concin N, et al: Expression and promotor hypermethylation of miR-34a in the various histological subtypes of ovarian cancer. BMC Cancer 16: $102,2016$.

45. Cui X, Zhao Z, Liu D, Guo T, Li S, Hu J, Liu C, Yang L, Cao Y, Jiang J, et al: Inactivation of miR-34a by aberrant $\mathrm{CpG}$ methylation in Kazakh patients with esophageal carcinoma. J Exp Clin Cancer Res 33: 20, 2014.

46. Samuel N, Wilson G, Lemire M, Id Said B, Lou Y, Li W, Merino D, Novokmet A, Tran J, Nichols NE, et al: Genome-wide DNA methylation analysis reveals epigenetic dysregulation of microRNA-34A in TP53-associated cancer susceptibility. J Clin Oncol: pii: JCO676940, 2016.

47. Tanaka N, Toyooka S, Soh J, Kubo T, Yamamoto H, Maki Y, Muraoka T, Shien K, Furukawa M, Ueno T, et al: Frequent methylation and oncogenic role of microRNA-34b/c in small-cell lung cancer. Lung Cancer 76: 32-38, 2012.

48. Kristensen LS and Hansen LL: PCR-based methods for detecting single-locus DNA methylation biomarkers in cancer diagnostics, prognostics, and response to treatment. Clin Chem 55: 1471-1483, 2009. 